\title{
Trefoil Factor 1
}

National Cancer Institute

\section{Source}

National Cancer Institute. Trefoil Factor 1. NCI Thesaurus. Code C17330.

Trefoil factor 1 ( $84 \mathrm{aa}, \sim 9 \mathrm{kDa}$ ) is encoded by the human TFF1 gene. This protein is involved in the maintenance of the gastrointestinal mucosa. 